addition to coal-cutting machines, which had been devised to dispense with powder, or render its employment safe. The use of compre sed air had been attended by some measure of success, and the dispersion of water, used as tamping, by the explosion of a powder charge in the form of a spray, had been shown to have frequently, thongh not reliably, the effect of drowning the flame developed by the explosion. The employment of water-columns, by which the force developed by the detonation of dynamite was uniformly transmitted throughout the entire length of the hole, had been proved, by experiments in coal-mines in Lancashire, and special test-experiments at Cardiff, to render that material very suitable for coal-getting, and at the same time to render blasting possible without liberation of flame. Lastly, the employment of cylinders or cartridges of compressed quicklime, according to a simple system elaborated by Professors Smith and Moore, was referred to as ranking before all other methods of getting coal, yet proposed, in point of simplicity, cost, and above all, safety, and the lecturer described operations witnessed by himself with this system of coal-getting at Shipley Collieries. In concluding, Mr. Abel exhorted those intecested in, or entrusted with the working of coal-mines, to spare no pains to test rigorously and fairly the merits of any processes or methods of affording promise of dispensing with the employment of powder in the ordinary way, and thus of securing protection to the miner against combined dangers of fire-damp and dust.

\section{THE INFLUENCE OF TEMPERATURE ON} CERTAIN SEEDS

$\mathrm{O}^{\mathrm{N}}$ regarding seeds of our hardy trees which are sown in autumn, and which do not germinate before the return of spring, we feel forced to admit that however the other conditions may vary, the cause which causes the germination in the commencement of the fine weather is the rise in the temperature, and one is equally tempted to think that the higher the temperature, as long as this rise does not equal that which would destroy the seeds, the more active and pronounced would be the germination. Nevertheless this is not by any means always the case, at any rate in the seeds of the walnut and almond trees. Anxious to germinate some of these seeds in winter, Prof. H. Baillon thought to obtain a more rapid development in a warm house, in which the temperature varied within the twenty-four hour from $15^{\circ}$ to $25^{\circ}(59-77 \mathrm{~F}$.), than in a cool huuse in which during the same time the temperature varied between $5^{\circ}$ and $15^{\circ}(41-$ $59 \mathrm{~F}$.$) , but the trial proved a failure. In the cool-house, in the$ course of six weeks, the walnuts had stems of about two decimetres in height, whereas the most advanced of those in the warm house had only stems of from two to three centimetres in the fully developed leaves. The experiment was several times repeated. The same quality of earth, and the same quantity of water was used, and the results were the same. After a space of two aud a half months the greater part of the nuts sown in the warm house had only roots occasionally well developed, but little or no caulome outside the fruit. Moreover, the greater part of the walnuts which germinated in a house, where there was good bottom-heat, had roots which did not behave like those of walnuts, germinating in the cool house and without bottom heat, the tap root of the latter grew well in length before any egress of the plumule, whereas the tap-roots of those grown in the warm house were early arrested in their development, and this through growing in a very friable soil, consisting of moist sawdust, much less resisting than the sand or the earth of the cool-house, in which the tap-roots developed so well. This was very nearly the same with the almonds, and would seem to point to the fact that in the case of some seeds there is no advantage to be gained by forcing them. Some, like Eranthis hiemalis, at whatever period they are sown in the open air, will develop themselves at a fixed time, as it does in January ( $H$. Baillon in No. 39 of the Bulletin Periodique de la Soc Linn. de Paris, January, 1882.)

\section{UNIVERSITY AND EDUCATIONAL}

\section{INTELLIGENCE}

Prof. Henry Alleyne Nicholsos has been appointed to the chair of Natural History in Aberde.n, vacant by the removal of Prof. Cossar Ewart to Edinburgh.

Dr. SORBY, F.R.S., has been elected president of Firth College, Sheffield.
THE Nottingham University College Committee have appointed Mr. Wm. Garnett, of St. John's College, Cambridge, to the Professorship of Mathematics and Physics, at the College, vacant by the resignation of Prof. Fleming.

\section{SCIENTIFIC SERIALS}

American Fournal of Science, April.-The wings of pterodactyles, by O. C. Marsh.-Sandstones having the grains in part quartz crystals, by A. A. Young.-Notes on American earthquakes, No. II, by C. J. Rockwood. -Notes on the electromagnetic theory of light, No. I, by J. W. Gibbs.-The "timber line," by H. Gannett.-Simple method for calibrating thermometers, by S. W. Holman. - Notice of Fisher's " Physics of the Earth's Crust," by C. Dutton.- - Yhysiological optics, No. III., by W. L. Stevens. - Great dyke of Foyaite or Elœolite-syenite in North-Western New Jersey, by B. K. Emerson.--Notice of the remarkable marine fauna occupying the outer bank off the southern coast of New England, No. 5I, by A. E. Verrill.Determination of phosphorus in iron, by J. L. Smith.

Fournal a'e Physique, March.-On the electro-chemical equivalent of water, by M. Mascart.- Studies on the psychrometer, by M. Angot.-Electric Lighting (concluded), by M. Foussereau. Determination of the ventral segments of sonorous tubes by means of manometric flames, by M. Hurion.-Compensator for measuring electromotive forces, by M. Slouguinoff.-On phosphorographs of the solar spectrum, by M. Becquerel.

A pril.-On a simple law relative to natural magnetic double circular refraction, by M. Cornu. - Determination of the illuminating power of simple radiations, by MM. Crova and Lagarde.-Measurement of potentials corresponding to determinate explosive distances, by M. Baille.--Study on the combustion of explosive gaseous mixtures, by MM. Mallard and Le Chatelier. - New dry sensitive thermometer, by M. Michelson.

Sitzungsberichte der physkalisch-medicinischen Societät zu Erlangen, I3 Heft, November, 1880, to August, 1881.-On the action of the milk-juice of Ficus carica, by A. Hansen.-On the artificial production of double-formations in chickens, by L. Gerlach.-On intra-thoracic pressure, by J. Rosenthal.-On the law of dispersion, by E. Lommel.-A polarisation apparatus from platincyanide of magnesium, by the same.-The germinal plates of Planaria, by E. Selenka.-Contributions to the theory of binary forms, by M. Noether.-Observations on the compo sition ard exchange of material of the electrical organ in the torpedo, by $\mathrm{T}$. Weyl.- On a new way of permanently fixing small anatomical objects for the purposes of demonstration, and preserving them without use of alcohol, ky L. Gerlach.-On the compression of drugs, by J. Rosenthal.-On the influence of chemical agents on the amount of assimilation of green plants, by T. Weyl.

Rivista Scientifico-Industriale e Giornale del Naturalista, January 31.-Mode of rendering the Holtz machine more active, by C. Marangoni.- The radiometer and school experiments, by C. Rovelli.-On a Querquedula new to Italy, by A. Fiori.-New applications of the pneumatic method for rapid desiccation of large Orthoptera, \&c., by P. Stefanelli.-Preparation of Hemiptera, by G. Cavanna.-Contribution to the study of anthropology of the Southern Provinces, by M. del Lupo.

February 28.-Nephoscope of P. F. Cecchi.-On the synthesis of various organic acids, by Drs. Bartoli and Papasogli, through electrolysis of water and of acid on alkaline, \&c., solutions with carbon-electrodes, by P. Guasti.-Differential apparatus for determining the ozone in air, by D. Tommasi.-Observations on the habits and the development of Aschna cyanta, Muill., by P. Stefanelli.

March I 5.-On Lebia turcica, Fab., by F. Piccioli.--Lombard palæontology; fossil fauna of Lombardy, by A. Stoppani.

Racle Istituto Lombardo di Scienze e Lettere. Rendiconti, vol. xv. fasc. iv.-On some fossil insects of Lombardy, by F. Sordelli.Some theorems on the degenerate forms of ellipsoid of Culmann, by G. Jung.- The double quadratic transformation of space (continued), by F. Aschieri.-Geometrical construction of the universal transformation of the third order, by $\mathrm{E}$. Bertini.

Fasc. v. - Reduction of integrals of algebraic functions to integrals of rational functions, by C. Formenti, - What are the most simple and sure means of radical cure of hemorrhoidal varices? by A. Scarenzio.-Aberrations of the sexual sentiment 
in a gynæcomastic maniac, by A, Raggi.-On varied systems of forces, by G. Bardelli.

Fasc. vi.-Origin of the Tractus olfactorius and structure of the olfactory lobes of man and of other mammalia, by C. Golgi. -Some theorems on the development in series by analytic functions, by $\mathrm{S}$. Pincherle.

Atti della R. Academia dei Lincei, vol. vi., fasc. 7.-On the tombs and dwellings of Iberian families existing in Italy, by L. Pigorini.

Natura, March.-A heat-electrometer, by G. Gandini.-On the origin of electricity of thunderclouds (concluded), by F. G. Nachs.-Alpine meteorology, by P. F. Denza.

\section{SOCIETIES AND ACADEMIES LONDON}

Zoological Society, April 29.-Anniversary Meeting.Prof. W. H. Flower, F.R.S., president, in the chair-After some preliminary business the report of the council on the proceedings of the Society during the past year was read by Mr. Sclater, the secretary. It stated that the number of fellows on December 31, 188I, was 3213, against 3309 at the same time of the previous year. The total receipts for I88I had amounted to $25,8 \mathrm{rol}$., against 27,3881 . for 1880 . The ordinary expenditure for $188 \mathrm{I}$ had been $24,65 \mathrm{I} l$., against $24,753 l$. for $\mathrm{I} 880$; and the extraordinary expenditure $1036 l$, against $1825 l$. for the preceding year. The sum of $1000 l$. had been devoted to the repayment of the mortgage debt on the Society's freehold premises, which had thus been reduced to $6000 l$. This expenditure had left a balance at the bankers of $1203 l$. to be carried forward for the benefit of the present year. The assets of the Society on December $3 \mathbf{I}$ last, after payment of all liabilities, were estimated to amount to nearly $20,000 l$., exclusive of the value of the library and collection of living animals. As regards the gardens in the Regent's Park, little has been done in the way of special works during $\mathrm{I} 88 \mathrm{r}$, but the buildings and walks had been kept in good repair, and several of the former had been thoroughly repaired and painted. The number of visitors to the Society's Gardens in $188 \mathrm{I}$ had been 648,604 , against 675,979 in 1880 . The zoological lectures having been well attended during the past year, would be continued during the present season. The number of animals in the Society's collection on December $3 \mathrm{I}$ last was 2294, of which 6I7 were mammals, 1389 birds, and 258 reptiles. Eleven mammals, I 7 birds, and I I reptiles belonging to species new to the collection had been exhibited in 188I, and during the same year a considerable number of mammals, birds, and reptiles of a different species (of which detailed lists were given) had reproduced their *kind in the Society's Gardens. - it was moved by Viscount Powerscourt, seconded by Mr. Howard Saunders, that the best thanks of the meeting be given to the Council for their report. The motion having been adopted, the meeting proceeded to elect the new Members of the Council and the officers for the ensuing year, and a formal ballot having been taken, it was declared that Mr. H. E. Dresser, Prof. Mivart, F.R.S., Mr. Henry Pollock, Mr. W. Ayshford Sanford, and Capt. George E. Shelley had been elected Members of the Council in place of the retiring Members; that Mr. F. Du Cane Godman had been re-elected into the Council in the place of $\mathrm{Mr}$. Edward R. Alston, deceased ; and that Prof. Flower, LL.D., F.R.S., had been re-elected president, Mr. Charles Drummond reasurer, and Mr. Philip Lutley Sclater, M.A., Ph.D., F.R.S., secretary to the Society until the next anniversary.

Physical Society, April 22.-Prof. Clifton, president, in the chair.-New member, Dr. E. Hopkinson. - The president announced that copies of the Report of the Lightning Rod Committee could be obtained from Dr. Guthrie, Science Schools, South Kensington, price five shillings per copy. - A paper was then read by Mr. W. F. Stanley on the evidence of a flowing liquid moving by rolling contact upon the interior surface of a pipe. In his experimental work on fluids, published last year, the author has endeavoured to show that liquids flowing in a tube move by rolling contact on or past the resistent surfaces of solids, and upon like principles that the moving parts of a flowing liquid move by rolling contact on the more quiescent parts 'of its own mass, so that in no case is there any element of sliding, gliding, or shearing motion such as is generally assumed. Further experiments tend to support this view in the case of liquids flowing through pipes. The difficulty in the experiments arose from the friction of the pipe impeding the free motion of the particles. The principle was investigated by allowing liquids o various kinds, such as solution of mastic varnish, to flow through pipes, the liquids containing colouring miatter, or air particles to assist the eye. The author illustrated the effects by diagrams on the screw.-Dr. W. H. Stone, Mr. Blaikley, Dr. Guthrie, and the President, offered some remarks on the paper.-Mr. J. M. Whipple exhibited the magnetograph curves obtained at the Kew Observatory during the past week, showing the progress of the recent magnetic storms. After stating that two unusually large spots were now passing over the sun's disc, he remarked that although the magnets at Kew were somewhat disturbed on

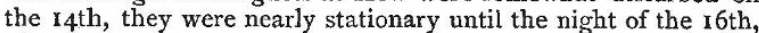
when, about 11.45 p.m., they became strongly affected, and from then tiil $8 \mathrm{p.m}$. on the $\mathrm{I} 7 \mathrm{th}$, the magnetic storm raged. The horizontal component of the earth's magnetic force was at one time reduced more than $0.05 \mathrm{~mm}$. mgrs. below its average value, and the vertical component by about 0.07 of the same units. This happened about $6 \mathrm{a} . \mathrm{m}$. of the 17 th. A little after noon of the same day both forces became so increased, that the light spot left the scale of the instrument for nearly two hours. A second period of magnetic disturbance conmenced at about $3.40 \mathrm{a.m}$. of the 20th, and was violent up to 2 p.m., subsiding gradually until 7.45 p.m. of the 2 Ist. During this period, the magnetic force, though fluctuating largely, did not experience such great changes of intensity as were indicated by that of the I Ith. Mr. Whipple then alluded to the work of Prof. W. G. Adams, and suggested that sun-spots only produced such effects when cutting certain lines of force, which he imagined might extend for a limited angular distance round the earth's radius vector. Prof. Adams pointed out the desirability of increasing the number of selfrecording magnetic observatories, especially in the southern hemisphere, and after mentioning that the French were about to equip such an observatory at Cape Horn, expressed the wish that the Cape of Good Hope Observatory might again be provided with magnetometers. - The Rev. S. J. Perry remarked on the exceptional nature of the storm which he had seen recorded at Brussels, and stated that in Belgium the telegraph service had been disorganised by it. Attention was also called to the auroral displays in America, and Mr. Lecky, Dr. Guthrie, the President, and others, spoke on the general phenomena of the storms. - It was then announced that the meetings of the Society in May would be held on the 6th and 20th, instead of on the $13^{\text {th }}$ and 27 th, as previously announced; also that the Society would hold a meeting at the Clarendon Laboratory, Oxford, on June 17, by invitation of the president.

Victoria (Philosophical) Institute, May I.-Prof. Reinsch gave the results of his researches into the mode of the formation of coal. The lecture was illustrated by several large drawings and photographs. The professor stated that he had examined with the microscope no less than 2500 sections of coal, and had come to the conclusion that coal had not been formed by the alteration of accumulated land plants, but that it consisted of microscopical organic forms of a lower order of protoplasm, and aithough he carefully examined the cells and other remains of plants of a higher order, he computed that they have contributed only a fraction of the matter of coal veins, however numerous they may be in some instances, he referred to the fact that Dr. Muck, of Bochum, held that algæ have mainly contributed to the formation of coal, and that marine plants were rarely found in coal, because of their tendency to decompose, and that calcareous remains of mollusks disappeared, on account of the rapid formatiou of carbonic acid during the process of carbonic action.

Royal Horticultural Society, March 28.-Sir J. D. Hooker, in the chair.-Savagus floccosus: Mr. Pascoe exhibited specimens of this beetle from Queensland, attached apparently by a species of Isaria, while living.-Doryanthes Palmeri: Sir J. D. Hooker exhibited a leaf, some five feet long, and a cluster of flowers from a spike twelve feet in length, bearing a fanicle of flowers, eighteen inches in length.-Coryanthes macrantha, exhibited by S.T. Laurence; the fertilisation of which, by insects, is described by Mr. Darwin, in his "Fertilisation of Orchids"

\section{EDINBURGH}

Royal Socety, April I7.-The Rev. Dr. Lindsay Alexander, vice-president, in the chair.-Prof. Blackie communicated a paper on the definite article in Greek, with special reference to the revised ver:ion of the New Testament. He showed by quo- 